\title{
Scaffolding Strategies in Promoting Attitudes of Saudi Middle School Science Students
}

\author{
Khaled Saleh Alrawili ${ }^{1}$, Kamisah Osman ${ }^{2 *}$, Saeed Saleh Almuntasheri ${ }^{3}$ \\ ${ }^{1}$ Faculty of Education, Universiti Kebangsaan Malaysia, MALAYSIA \\ ${ }^{2}$ Center for Teaching and Learning Innovation Faculty of Education, Universiti Kebangsaan Malaysia, MALAYSIA \\ ${ }^{3}$ Faculty of Education Albaha University, SAUDI ARABIA \\ * Corresponding author: kamisah@ukm.edu.my
}

Received: 16 Sep. $2021 \bullet$ Accepted: 9 Nov. 2021

Citation: Alrawili, K. S., Osman, K., \& Almuntasheri, S. S. (2022). Scaffolding Strategies in Promoting Attitudes of Saudi Middle School Science Students. European Journal of Science and Mathematics Education, 10(1), 71-86. https://doi.org/10.30935/scimath/11385

\begin{abstract}
:
Developing teaching strategies has become the cornerstone of education. The most successful educational strategies are those that adhere to their vital role to students as they focus on raising the students' attitude towards learning. This research shed some light on the impact of scaffolding strategies on middle school students' attitudes towards the science subject. Specifically, the aim of this research is twofold: to examine students' attitudes towards learning and enjoying science and to emphasise their attitudes towards science teachers and their teaching methods in the classroom. A quasiexperimental research design was implemented to achieve the research objectives involving pre- and post-test for the experimental and control groups. The research population consisted of 84 ninth-grader science students in Saudi. A questionnaire of 24 items was developed to cover the major dimensions of the study after being validated by relevant experts. After conducting the questionnaire, data were collected accordingly and then analysed using descriptive analysis and inferential statistics. Findings showed a significant difference in the science student's attitude in favour of students who were taught using scaffolding strategies compared with those taught using conventional teaching methods. Based on the findings, the research proposes that scaffolding strategies should be applied as educational venues of learning autonomy to students in classrooms that directly and indirectly promote students' positive attitudes towards learning science. The research concluded with a recommendation that scaffolding strategies should be applied when teaching science for better outputs. Therefore, policymakers and curriculum planners need to adopt scaffolding as a typical teaching strategy for the art of teaching in general and science in particular.

Keywords: attitudes toward science, middle school, scaffolding strategies, science education
\end{abstract}

\section{INTRODUCTION}

Science is defined as a collection of empirically supported, systematic and objective information that removes people from preconceived notions (Cermik \& Fenli-Aktan, 2020). Regarding individual actions, attitude may be described as a learned internal state that influences the person's decisions concerning other people, events and various circumstances (Senemoglu, 2018). Students' perspectives regarding science are also important variables in determining their learning and success in scientific classes (Osborne et al., 2003). Several studies showed that adopting engaging instructional methods may help students develop more positive attitudes about learning (Altiparmak, \& Eryilmaz-Muştu, 2021; Artino, 2012). According to a growing corpus of research, increasing evidence shows that the relationships between students' attitudes about science and their performance in science are favourable (Liou, 2014; Liou et al., 2020; Ural \& Gençoğlan, 2020). However, how students' attitudes about science function as mediators in the relationships between instructional methods and student performance in science classes is still unclear. 
Overstating the significance of students' attitudes towards science is impossible because they are necessary psychological preconditions for participation in the areas of science, technology, engineering and mathematics (STEM) (Osborne et al., 2003). Additionally, the Next Generation Science Standards (NRC, 2012) inform practices not only in the United States but also worldwide. Given its introduction, favourable perceptions towards science are necessary to achieve the vision that students engage with scientific practices and cross-disciplinary concepts to develop a deep understanding of scientific concepts. Students' attitudes towards learning, from another aspect, are conceptualised in a variety of ways (Liou, 2021; Osborne et al., 2003; Pekrun \& Marsh, 2018).

Hence, education becomes one of the most significant components of the intellectual domain's educational programme (Darling-Hammond et al., 2020). In educational systems, the targeted cognitive development and affective behaviours are mostly related to students' positive or negative tendencies towards related subjects, individuals, events or ideas. Alternatively, they are demonstrated briefly about their attitudes towards these subjects and individuals (Ugulu, 2015). Moreover, fostering good scientific attitudes is an essential aim in science education as research showed that attitudes about science are the precursors of interest in choosing a career in science and taking science courses (Azevedo, 2018).

In science education, several studies have been devoted to determining more convenient approaches that can raise the enrolment of various courses and degrees of science by developing the quality of science education in general. Hence, determining the key factor that can help to achieve this ultimate objective becomes crucial. George (2006) noted that the element of students' attitudes is a key factor in learning science. Such an element can enhance positive attitudes towards science and can positively motivate students' interest either in the subject of science or in various science-related tasks. Promoting a positive attitude towards science subjects is one of the most significant objectives of the science curriculum (Cheng \& Tsai, 2020; Thomas et al., 1985). Hence, attitudes can be described as common characters that play a vital role in emotional feelings and the evaluation of an individual. The reason is that an attitude emerges from the needs, expressions and intellectual processes of humans (Tayeb et al., 2014).

Science learning processes are affected by positive and negative attitudes, and thus, they become effective responses that involve a feeling of responsible stability and intensity. In other words, attitude is an individual's emotional response to a sense of satisfaction or dissatisfaction towards people, things, places or ideas (Papanastasiou \& Papanastasiou, 2004). One of the essential objectives of scientific education is to instil a positive attitude towards science amongst students (Darling-Hammond et al., 2020). A positive attitude towards science indicated that students are confident in learning science and they enjoy the learning process. In this research paper, the concept of motivation is related to students' attitudes with their interests. This concept is supposed to affect their attitudes to learning science, and it directly affects their academic results. Attitudes are believed to have an effect on science learning, where the more positive the attitude of students, the better their expected learning. In this research, the attitude towards science was measured using students' attitude questionnaire.

One of the most popular learning models is the '5Es Model', which is implemented in five stages: Engagement, Exploration, Explanation, Elaboration and Evaluation (Carin et al., 2005; Lorsbach, 2006). In this model, every stage has a particular function. This model helps teachers contribute a coherent instruction that leads to better understanding based on students' ability to formulate scientific knowledge, skills, and attitudes.

The 5Es model referred to the structure used by teachers, particularly in science subjects to meet the demand of today's standard and was formed based on the constructivist view of education (Ahmad et al., 2018; Chitman-booker \& Kopp, 2013). This model helps engage the way students think prior to allowing their explorative discovery and factual learning that will help deepen their understanding of the content matter. Not to mention, students were believed to process several ideas when they decide 
on whether they will commit to a topic (Pickering \& Marzano, 2011). Thus, when teachers adhere to the 5Es instructional model in teaching students about any scientific concepts, these teachers will be able to attend to every aspect of the students' perceptions consciously.

The significance of scaffolding comes in its ability to strategise the teaching of new skills. The main philosophy of scaffolding is collaboratively engaging students in unusual or difficult tasks by involving them in accomplishing those tasks independently. Within the Scaffolding Strategies (SS), the role of the teacher, and all other skilful persons, is just to guide learners and support their development whilst doing tasks on their own (Nonye \& Nwosu, 2011). Theoretically, teaching has been inspired by SS based on the socio-culture theory by Lev Vygotsky. His idea of Zone of Proximal Development (ZPD) provided a significant contribution to the art of teaching. According to sociocultural theory, social interaction plays a vital role in cognitive development. Hence, learners work on practising cooperative learning. They do not learn in isolation because they are affected by social interactions in their educational context. Thus, ZPD can be referred to as the distance between the student's ability to do a task alone and what is expected to be achieved based on the support of either other peers or teachers. The theory supposes that any concept taught can be learnt by any learner through performing scaffolding techniques.

As a teaching strategy, scaffolding relies heavily on the concept that students attend any educational environment with a preoccupation with obtaining correct or incorrect knowledge. Hence, the main task of scaffolding is to focus on the pre-obtained knowledge of a student so that an appropriate and effective strategy will be implemented to support and guide for better achievement. Casem and Alicia (2013) stated that the role of scaffolding is to facilitate the student's development through support that includes templates, resources, guides and tasks based on guidance inspired by the improvement of cognitive and social skills. Hence, the student's ability is facilitated and supported by scaffolds to internalise new information and build on the prior knowledge. In other words, scaffolding provides activities beyond just doing tasks individually. The temporal scaffolds that incorporate social skills to develop cooperative learning give students more power to cope with peculiar or complex tasks. Ibritam et al. (2015) argued that as the ability of students increases, the scaffolding contributes to producing a more knowledgeable person who can master the concept and accomplish the task independently. In the same vein, Dorn and Soffos (2001) maintained that scaffolding is considered the procedure by which a teacher or any proficient companion can use to help a student adjust any learning tasks.

Arguably, scaffolding can expand students' understanding so that they can learn from different perspectives and formulate new information based on the processes of learning and related knowledge. In this way, the teacher's role is to follow, monitor and realise the moments in which students can or are unable to accomplish any given tasks independently (Agu \& Iyamu, 2020). Additionally, scaffolding provides powerful guidance that provides customised help that fabricates students' certainty. It utilises illustrative input to make students comprehend and accomplish what they can improve and what they are doing appropriately and conveniently. The mentality of students towards a specific subject, such as science, predominates their learning regarding this school subject. Adodo and Gbore (2012) affirmed that the mind frame is the individual's tendency towards a specific thing, thought or foundation. They stated that such change is caused by the extensive attitude significance, which handles all aspects of character improvement, such as values, solitary interest, goals and proficient change gained from the interests of an expert in addition to different times of one's gradual lives.

Derez (2021) noted that students mostly find the science subject to be repetitious and boring. The reason beyond that might be the lack of enough opportunities given to students to develop their own understanding and apply their imaginations. Therefore, arguably, if students are inspired by their teachers and get encouraged to promote their own understanding, then they are supposed to be able to conceive that the subject of science is not related to the mere memorisation of formulas and terms. Rather, science is about cooperation and collaboration with others. This case brings into mind the significance of attitude to students' reactions towards various activities, programmes and events that 
can be exhibited in students' feelings, beliefs and emotions (Rosemond, 2006). Additionally, attitude can be implied as a latent variable or a psychological construct, which is reflected through observable responses to stimuli. Such stimuli are supposed to mediate coherence and consistency amongst those responses and exceed them to interpret the relationship between attitude and perceiving, feeling, thinking and behaving towards a certain cognitive object (Olatoye et al., 2011).

In Saudi Arabia, a few studies have been conducted on some features of Saudi students' attitudes towards science. For instance, Saif and Asiri (2017) examined if certain differences exist between Saudi students' attitudes towards science in terms of gender. They found that no significant differences exist in students' attitudes towards the science subject between the results allotted from boys and girls. Earlier, Al-Shargi (1987) reported that Saudi secondary school students have negative attitudes towards science. Therefore, the current study comes to deal with science education as a significant issue in Saudi Arabia.

The Saudi education system is suffering from weak instructions, poorly trained teachers, a lack of rigorous standards and low retention rates (Alharbi, 2015). Additionally, the education system in Saudi Arabia has been criticised for its need for more effective learning strategies such as scaffolding, the focus of the current study (Almuntasheri et al., 2016). Hence, the necessity to address the current issues faced by the education system in Saudi Arabia could play an important role in improving the overall education quality in the near future. To the best knowledge of the researcher, no study has examined the effect of SS on Saudi students' attitudes. This research has been devoted to bridging this gap, relying on the belief that if learning is related to real-world issues, then student attitudes will increase to learn science as they live these issues and dilemmas. In other words, attitudes and motivation are sustained through real-world issues and projects (Jorde \& Dillon, 2012).

Recently, the government of Saudi Arabia has significantly invested in the development of its science education sector with a particular focus on the new science curriculum. This new science curriculum emphasises the current teaching and learning trends to make a learner-centred environment with inquiry-based instruction (Obeikan, for Research and Development, 2010). According to Alrwathi et al. (2014), this case is only possible when the teachers have been well-trained and their classroom practices high standards. Consequently, the new education reforms will not occur until the teachers are equipped with modern requirements, such as SS to implement appropriate teaching practices. Almazroa and AlShamrani (2015) pointed out that this initiative to reform science education in Saudi Arabia has shifted from conventional teaching styles to more progressive and inquiry-oriented methods. According to Mansour and Al-Shamrani (2015), adequate support is needed to help Saudi teachers approach such professional teaching. Some problems are associated with the ministry or administrative support that Saudi teachers experience when engaging in professional development programmes. The most significant issues included insufficient programmes to encourage involvement in professional development programmes, a lack of training programmes and heavy teaching responsibilities. This research paper sheds some light on how this new curriculum can be reinforced to develop science students' attitudes under the umbrella of SS.

The educational concept of scaffolding can be associated with the constructivist learning theory, where constructivism involves knowledge construction through active rather than passive processes. Experts of this theory, namely Bruner, Dewey, Piaget and Vygotsky, are not only to the side of the notion of scaffolding but also supporters to change the learners' role as passive recipients of knowledge. Learners need to be involved actively in the construction of knowledge (Hausfather, 2001). Hence, the focus is on learning carried out by the students themselves, not the content imposed on them. Kiong and Yong (2001) explained that learners should deal with active creators of their knowledge by generating new concepts related to their knowledge. Lajoie (2014) asserted that scaffolding can be used as cognitive support for motivation and problem solving to help learners realise their potential. Learning task is challenging for teachers and students' model; the task to become more confident and competent (Azevedo \& Hadwin, 2005; Lajoie, 2005; Pea, 2004). 
Scaffolding indicates that the teacher is aware of the needs of students so that they can be supported when certain skills or understanding requires interference to accomplish a specific task at a certain period. Hence, planning to use the most appropriate forms of scaffolding is based mainly on teachers' professional insight towards their students being disciplined at a particular task. Additionally, SS require teachers to understand how supporting these educational techniques fall within the student's ZPD (Renken et al., 2016). Based on ZPD, students can do with or without their teacher's assistance, and their ability to accomplish certain tasks on their own is gradually improved. What is needed for applying SS is the assistance and guidance of knowledgeable and professional teachers. However, recent empirical support for attitudes as learning tools has emphasised conceptual understanding (Kim et al., 2015; Renken et al., 2016). Consequently, this research has been conducted to prove the role of attitudes in promoting students' knowledge and understanding under the umbrella of scaffolding.

To summarise, scaffolding is an effective learning strategy that relies on more interaction amongst learners and promotes the ability to foster bonding amongst them. The role of an instructor is just a key driver for successful learning. Additionally, the educators can enrich learners' knowledge by collecting and understanding various datasets of the students' profiles to obtain their progress and development. In Saudi Arabia, the need is to examine the effect of scaffolding encompassed with attitude as it plays a vital role in achieving the ultimate goal of the science curriculum. Coming to the point, this research comes to examine the effect of scaffolding on students' attitudes.

\section{Conceptual Framework and Questions of the Study}

The conceptual framework of the current study is based on the combination of scaffolding and 5Es under the umbrella of constructivism theory and ZPD and how they supposedly affect learners' attitudes. Scaffolding is well known to most people as an effective strategy for student learning, specifically as it is considered a temporary support adapted to the understanding of a student (Van de Pol et al., 2010). According to Van de Pol et al. (2019), the central concept behind scaffolding can frequently be connected to the sociocultural theory developed by Vygotsky. The 5Es model, according to Bybee and Landes (1990), can be utilised to plan a science lesson, constructivist-learning hypothesis and best practices in science educating. Bybee (1997) announced that 'utilizing this methodology, understudies reclassify, revamp, expound, and change their underlying ideas through self-reflection and association with their companions and their condition. Students decipher items and marvels, and disguise those translations regarding their current reasonable comprehension'.

This research focuses on the effects of SS and the 5Es model on the attitude of ninth grade male students in Saudi Arabia who study science courses. To date, a good number of studies have examined students' attitudes towards learning by using SS (Barak \& Dori 2009; King et al., 2013; Yee et al., 2015). SS and the 5 Es stages are combined to measure the effect on learners' attitudes. However, this study has chosen Bybee (1997) the 5Es module because the respondents of this study are young learners (i.e., grade 9 male science students). In addition, this study believes that combining these approaches will make learning activities more interesting for the students. As such, the incorporation of such teaching techniques will enhance student's attitudes.

Scaffolding and reciprocal teaching are effective strategies to access the ZPD. It allows a teacher to provide students with the ability to develop their existing skills and expertise. Teachers must engage students' attention, reduce activities such that they are achievable and inspire students to achieve the educational objective. In addition, the teacher must seek a difference between the student's efforts and the response, awareness and the models as an idealised version of the act (Hausfather, 2001).

Hence, teaching strategies, in general, are grounded by the constructivism and scaffolding theories. In their previous study, Chang et al. (2009) proposed meaningful generalisation and association of the teaching strategies by inter-relating Piaget's constructivism theory with SS through Vygotsky's sociocultural theory. 


\section{METHODOLOGY}

\section{Research Design}

This research relied on the quasi-experimental design study, where the given course is considered an 'intervention'. Hence, a treatment comprising the course elements is evaluated and tested. This research design reflects how well it achieves the research objectives, measured by a pre-specified set of indicators (Fraenkel \& Wallen, 1996). The quasi-experimental approach was used to answer the study question and examine the effect of educational SS on science students' attitudes enrolled in the ninth grade of middle school in Saudi Arabia. The science topic used in the intervention is the second Chapter (Earth Changes) of the science syllabus. The same topic was taught for the experiential group using SS that focus on students' attitudes and the control group using the conventional method. Table 1 summarises the design of the study.

Table 1. Quasi-experimental research design

\begin{tabular}{lccc}
\hline Group & Pre-test & Treatment & Post-test \\
\hline EG & SQ & SS & SQ \\
CG & SQ & Conventional & SQ \\
\hline
\end{tabular}

Note

EG: Experimental Group

CG: Control Group

SQ: Students' Questionnaire

SS: Scaffolding Strategies

Whilst conducting the current study, three main elements were considered to minimise the threats to internal and external validities of the research. The first is related to the group selection where only male students of grade 9 were involved in the aforementioned topic. This case could limit threats of the external validity when encompassed with the rest of the course content and to generalise the results on female students. The second is the differences between the experimental and control groups paying attention to both equalities and the drop-out rate that can negatively affect the experimental group because of inequality. Finally, the third element is related to the maturation and the interaction of the selected groups and their appropriateness for assessing the experimental variables (Shadish et al., 2002).

\section{Study Sample}

The population of this research is the ninth-grade male students from a school ranked first in the area Saeed Bin Al-Musayeb School, Arar city, Saudi Arabia. This school is also a government Middle School for Boys, and the research was conducted in the academic year 2019-2020. A total of 84 students were chosen as a sample for this research. The required data were collected using the convenient sampling technique. A self-administered questionnaire was distributed amongst the students to measure the effects of SS on the attitudes of Saudi Arabian male students. Chronologically, students were closed in age ranging between 14 and 15 years.

For ethical issues, the researchers began the process of obtaining permission to carry out the questionnaire. Upon receiving written permission from the Ministry of Education (MoE) in Saudi Arabia based on a confirmation letter from the Saudi Arabia Cultural Mission in Kuala Lumpur, Malaysia, the questionnaire was then conducted to the participants. The questionnaire items were initially constructed in English, but as the subjects' language is Arabic, the items were translated to Arabic (the students' mother tongue) to help them understand the questions. The researchers gave the questionnaire to a native linguistic teacher for translation from English into Arabic.

\section{Teaching Procedure}

The teaching-learning process for the experimental and control groups was implemented based on the same syllabus. The process was conducted following the Science Curriculum Specifications addressed by the MoE, Saudi Arabia. The teaching process for the experimental group involved SS through the 
5Es model. For the control group, the conventional method was applied. After the course, pre- and posttest were carried out before and after the intervention was completed, respectively.

\section{Teaching Procedure for the Control Group}

The teaching-learning process for the control group required the use of the conventional method. The main role is given to the teacher. In other words, students are given only minor roles, and they should listen to their teacher's instructions. In this way, the control group is a teacher-dominated or teachercentred group. The time period for implementing the chapter chosen for the study was five weeks.

\section{Teaching Procedure for the Experimental Group}

The teaching-learning process for the experimental group involved using the experimental method in which the main role is given to students. In other words, students are given the main role, whereas the teacher's role is just to direct and guide. Hence, the experimental group is a student-centred group. Like the conventional group, the experimental group was given a five-week time period to implement the chapter chosen for the study.

\section{Instrument}

As mentioned earlier, the instrument used for obtaining the research data is a questionnaire composed of a total of 24 items. The items were equally distributed on three main domains (eight items): attitudes towards learning science, attitudes towards enjoying learning science and attitudes towards science teacher and methodology. The questionnaire was developed by the authors based on Fraser (1981) and Grewal (1990) whilst considering the impact of SS on science students. After conducting the questionnaire to the participants, the reliability test was run using Cronbach Alpha to determine the internal consistency, which reached 0.83 .

An attitude scale was developed to measure the effect of SS to enhance students' attitudes towards science amongst the ninth graders. Before conducting the questionnaire, it was validated by experts who are professors in education, and then, modifications were carried out based on their relevant suggestions. The attitude scale aimed to measure students' attitudes towards science before and after the experiment for both groups.

The questionnaire was evaluated by two referees of Arabic origin who are fluent in English. The translated version was also compared with the original English version, and the two versions were found to match each other. Later, the content validity of the questionnaire was evaluated by four referees who are science teachers. The suggestions of the referees were then incorporated into the final Arabic version. The students were assured that all their feedback would be kept confidential. Their help was needed to report any difficulties that might arise in the course of answering the questionnaire. The instructions for the questionnaire items were in Arabic, and the researchers expected the respondents to understand the items.

Certain important points were considered whilst making the scale, including the scale items that should be specific and include one idea to express a specific attitude. Additionally, the items were related to the domains of scale as well as the attitude subject. Another critical point is that the items were short as much as possible, and they were easy and suitable to the level of students. The five-point Likert scale was used to measure the responses of students. The levels of the responses dwindled between strongly agree (SA), agree (A), not sure (N), disagree (D) and strongly disagree (SD).

To respond, students were required to tick $(\sqrt{ })$ their responses. After modification, the final scale version consisted of 24 items distributed into three domains. The first domain deals with students' attitudes towards learning science, as shown in Table 2. 
Table 2. First domain: attitudes towards learning science

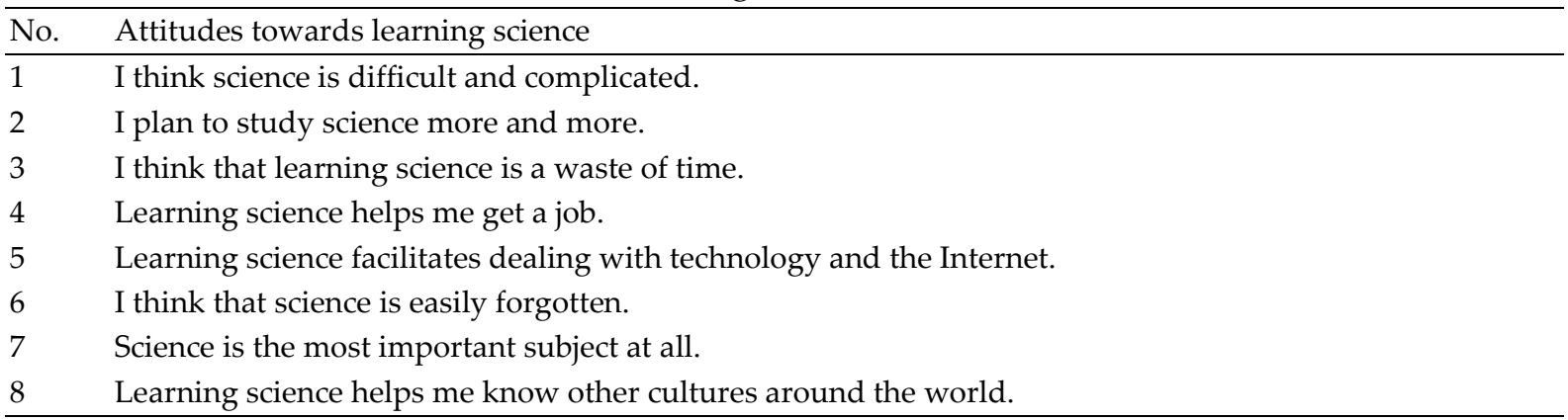

The second domain of the scale deals with the students' attitudes towards enjoying learning science. This domain reflects the students' feelings towards learning science, and this kind of enjoyment affects their performance in the classroom and in their free time, as shown in Table 3.

Table 3. Second domain: attitudes towards enjoying learning science

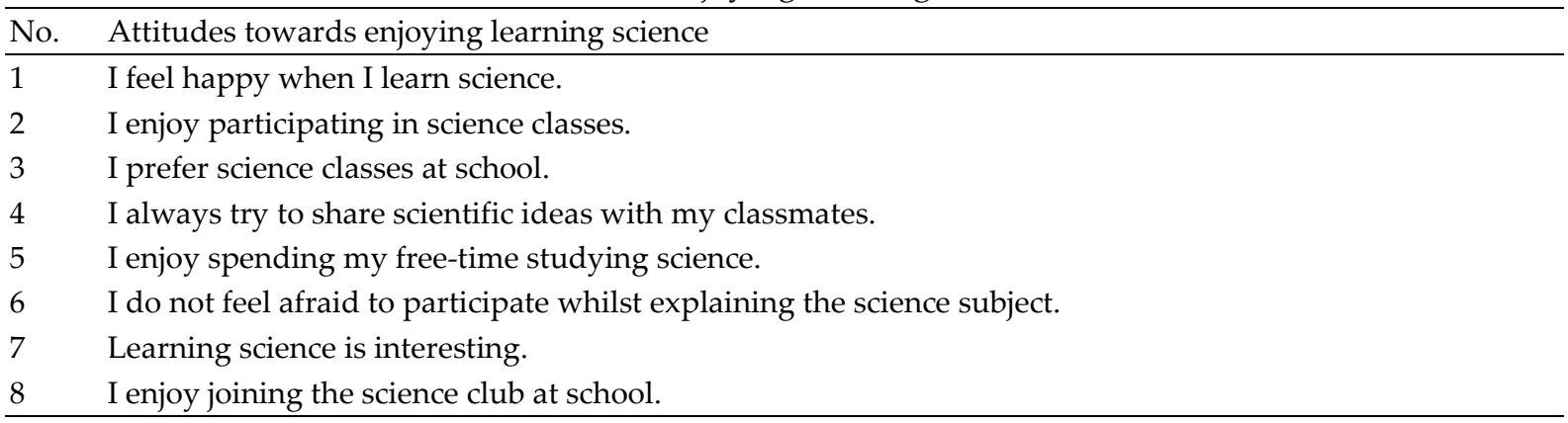

Finally, the third domain tackles students' attitudes towards the science teacher and teaching methodology. In this domain, students are required to reveal their impression of their science teacher and how they are given opportunities to participate in various activities, as shown in Table 4.

Table 4. Third domain: attitudes towards the science teacher and methodology

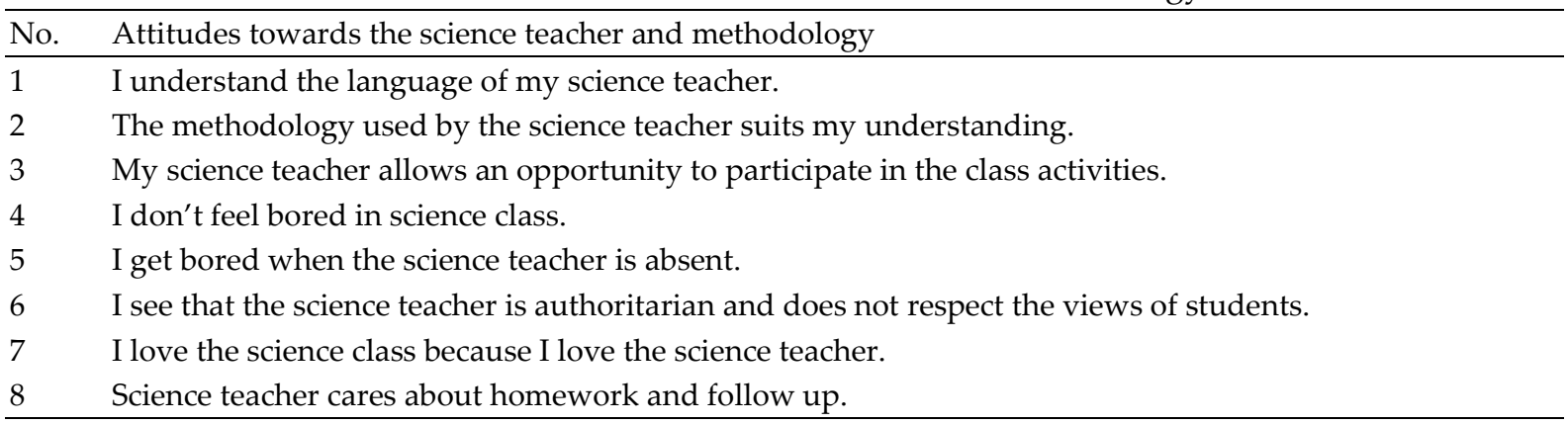

To avoid ambiguity, the researchers instructed the students how they can share their own opinions by ticking $(\sqrt{ })$ the choice appropriate to them. The scale statements were translated into Arabic to help students understand the scale items accurately.

\section{DATA ANALYSIS}

Before executing any statistical analyses, researchers ensured that all test assumptions were not violated. Almost, testing of assumptions requires descriptive statistics on the research variables. According to Pallant (2000), descriptive statistics include the mean, standard deviation, range of scores, skewness and kurtosis. Moreover, an independent sample t-test was run to explore the differences between the two groups (Sekaran, 2003). This was needed for this research because of the need to compare the mean scores between groups. Additionally, paired sample t-test (Samuels \& Gilchrist, 2014) was used to compare the means of data from two related samples. However, paired sample t-test was 
used because this research needs to compare the mean. Consequently, a one-way analysis of variance (ANOVA) test was run to determine whether differences exist in the means of a continuous dependent variable across a set of two. The aim beyond running ANOVA is to confirm any differences amongst the means of two groups (DeCoster, 2006). If the ANOVA test is significant, then the groups have means that are significantly different from each other. Data skewness and kurtosis were run to confirm the data normality (Tabachnick \& Fidell, 2019). The range of skewness and kurtosis was between +1.96 and 1.96, as shown in Table 6.

Table 5. Descriptive statistics of the participants $(\mathrm{N}=84)$

\begin{tabular}{lll}
\hline Characteristics & $\mathrm{N}$ & $\%$ \\
\hline Group & & \\
Experimental & 42 & 50 \\
Control & 42 & 50 \\
\hline
\end{tabular}

Table 6. Skewness and Kurtosis for the variables

\begin{tabular}{lcccc}
\hline Variable & Skewness & SD & Kurtosis & SD \\
\hline Pre-test attitudes & -.067 & 0.263 & -.704 & 0.520 \\
Post-test attitudes & -.553 & 0.263 & -.268 & 0.520 \\
\hline
\end{tabular}

\section{FINDINGS AND DISCUSSION}

Before testing the hypothesis (i.e., no significant difference exists in the level of attitudes towards science post-test between the experimental group who taught using SS-HOT AttAch module and control group who taught using conventional teaching methods), an independent sample T-test and ANOVA was conducted on the independent samples. The objective is to determine whether the groups are statistically homogenous and equivalent. The dependent variables of the research include three domains of attitudes, and the results revealed no significant differences in the variables test. In the initial analysis set, the difference between the two groups (experimental and control) was examined to determine attitudes towards learning science, attitudes towards enjoying learning science and attitudes towards science teachers and methodology on the basis of the 0.05 significance level. Initially, the independent sample t-test was carried out to evaluate the differences between means for the two groups in pre- and post-test for the skills. ANOVA and multivariate ANOVA (MANOVA) also were carried out to compare the differences between means for the two groups on pre-test and post-test.

ANOVA and MANOVA were conducted to identify whether a significant difference in the pre-test score for dependent variables exists between groups. ANOVA is usually applied when two or more groups test whether their population means are equal. Moreover, ANOVA should be selected when subscales are used because subscales are composite scores. Furthermore, MANOVA might be an appropriate way to analyse statistical significance amongst different dependent variables that can be varied between groups.

An independent sample t-test was conducted to test the difference between the two groups in students' attitudes post-test, and the result supported significant differences. For the experimental group, Table 7 shows the result $(\mathrm{F}=1.206, \mathrm{p}=.275, \mathrm{t}=4.226$, Sig $=.001<0.05)$.

Table 7. Results of independent sample T-test for variables attitude towards science post-test

\begin{tabular}{lccccc}
\hline Variable & F-value & $\mathrm{p}$ & $\mathrm{t}$ & $\mathrm{df}$ & Sig. 2 tailed \\
\hline Attitude towards science & 1.206 & .275 & 4.226 & 82 & .001 \\
\hline
\end{tabular}

Concerning descriptive statistics, the pre-test mean score (Mean $=2.87$, Standard Deviation $=.426)$ for the whole sample has a post-test score of $\mathrm{M}=3.08$ and $\mathrm{SD}=.460$ ). Separate scores were obtained by each score. The control group scored lower in pre-test attitude $(\mathrm{M}=2.86, \mathrm{SD}=.400)$ compared with the experimental group $(\mathrm{M}=2.88, \mathrm{SD}=.456)$. For post-test, the experimental group scored higher in attitude 
Table 9. Results of MANOVA for the between-subjects effect of the research variables: $p<.05$

\begin{tabular}{|c|c|c|c|c|c|c|}
\hline Source & $\begin{array}{c}\text { Dependent variable } \\
\text { post-test }\end{array}$ & $\begin{array}{c}\text { Type III } \\
\text { Sum of squares }\end{array}$ & $\mathrm{df}$ & Mean square & $\mathrm{F}$ & $\mathrm{P}$ \\
\hline Corrected & Attitude 1 Post-test & 8.203 & 1 & 8.203 & 17.593 & .001 \\
\hline \multirow[t]{2}{*}{ model } & Attitude 2 Post-test & 4.762 & 1 & 4.762 & 12.014 & .001 \\
\hline & Attitude 3 Post-test & .074 & 1 & .074 & .135 & .714 \\
\hline \multirow[t]{3}{*}{ Intercept } & Attitude 1 Post-test & 635.250 & 1 & 635.250 & 1362.40 & .001 \\
\hline & Attitude 2 Post-test & 589.360 & 1 & 589.360 & 1486.86 & .001 \\
\hline & Attitude 3 Post-test & 1255.50 & 1 & 1255.50 & 2280.83 & .001 \\
\hline \multirow[t]{3}{*}{ Group } & Attitude 1 Post-test & 8.203 & 1 & 8.203 & 17.593 & .001 \\
\hline & Attitude 2 Post-test & 4.762 & 1 & 4.762 & 12.014 & .001 \\
\hline & Attitude 3 Post-test & 4.762 & 1 & .074 & 135 & .714 \\
\hline \multirow[t]{3}{*}{ Error } & Attitude 1 Post-test & 38.234 & 82 & .466 & & \\
\hline & Attitude 2 Post-test & 32.503 & 82 & .396 & & \\
\hline & Attitude 3 Post-test & 45.138 & 82 & .550 & & \\
\hline \multirow[t]{3}{*}{ Total } & Attitude 1 Post-test & 681.000 & 84 & & & \\
\hline & Attitude 2 Post-test & 626.625 & 84 & & & \\
\hline & Attitude 3 Post-test & 1300.000 & 84 & & & \\
\hline
\end{tabular}

${ }^{*} \mathrm{p}<.05$

$(\mathrm{M}=3.28, \mathrm{SD}=.391)$ than its control counterpart $(\mathrm{M}=2.89, \mathrm{SD}=.446)$ over the time module. No statistically significant mean difference was found between students taught by the combined module of scaffolding and those taught using conventional teaching methods with respect students' attitudes. An inspection of the mean and standard deviation scores indicated that the experimental group reported a higher total attitude towards science $(\mathrm{M}=3.28, \mathrm{SD}=.391)$ than the control group $(\mathrm{M}=2.89, \mathrm{SD}=.446)$ as shown in Table 8.

Table 8. Summary statistics for attitude scores $(\mathrm{N}=84)$

\begin{tabular}{|c|c|c|c|c|c|}
\hline Variable & Test & $\mathrm{M} / \mathrm{SD}$ & Total sample & Experimental group & Control group \\
\hline \multirow[t]{4}{*}{ Attitude } & Pre-test & Mean & 2.87 & 2.88 & 2.86 \\
\hline & & SD & .426 & .456 & .400 \\
\hline & Post-test & Mean & 3.08 & 3.28 & 2.89 \\
\hline & & SD & .460 & .391 & .446 \\
\hline
\end{tabular}

With respect to attitude towards science sub-scales, this study also conducted MANOVA $(2 \times 3)$ with the subscales of attitude towards science (attitudes towards learning science, attitudes towards enjoying learning science and attitudes towards science teacher and methodology), with the independent variables presented in both groups (experimental and control). The initial set of analyses produced significant main effects for the dependent variables with the homogeneity of variance assumption unpinning MANOVA tested using the $\mathrm{M}$ box test. The result showed that the homogeneity of variance was not achieved in post-test (Box M = 32.976, F = 5.278, $\mathrm{p}=.001<0.05$ ). Therefore, the study used Pillai's Trace and Wilks Lambda criteria to examine the differences between the two groups. The results were statistically significance at Pillai's Trace (value $=.247, \mathrm{~F}=8.761, \mathrm{p}=.001<0.05$; Wilks Lambda, value $=$ $.753, \mathrm{~F}=8.761, \mathrm{p}=.001<0.05)$. Additionally, the result of the multivariate test showed differences between the groups in terms of attitude towards science subscales mean scores. The study compared the differences between the groups in the attitude towards science subscales. The result was significant on student attitude towards the nature of learning science scale (Mean Square $=8.203, \mathrm{~F}=17.593, \mathrm{p}=$ $.001<0.05$ ) and the interest in learning science (Mean Square $=4.762, \mathrm{~F}=12.014, \mathrm{p}=.001<0.05$ ). However, the result was insignificant for the influence of the teacher and teaching strategy scale (Mean Square $=.074, \mathrm{~F}=.135, \mathrm{p}=.714>0.05$ ) as shown in Table 9 .

Therefore, a significant difference exists in the mean score in the application and evaluation subscales post-test between the two groups. The students in the experimental group reported a higher student 
attitude towards the nature of the learning science scale mean score $(\mathrm{M}=3.06, \mathrm{SD}=.459)$ compared with their counterparts $(\mathrm{M}=2.43, \mathrm{SD}=.849)$. Moreover, students in the experimental group reported higher interest of learning science scale mean score $(\mathrm{M}=2.88, \mathrm{SD}=.502)$ compared with their counterparts (M $=2.41, \mathrm{SD}=.734)$. Despite the insignificant results for the influence of teacher and teaching strategy scale, the mean and standard deviation values presented in Table $\mathbf{1 0}$ show that students in the experimental group had higher mean influence of teacher and teaching strategy scale scores $(\mathrm{M}=3.89, \mathrm{SD}=.899)$ compared with students in the control group $(\mathrm{M}=3.83, \mathrm{SD}=.540)$.

Table 10. Summary statistics for variable post-test scores

\begin{tabular}{lccc}
\hline Variable & Mean/SD & Experimental group & Control group \\
\hline Attitude 1 & $\mathrm{M}$ & 3.06 & 2.43 \\
& $\mathrm{SD}$ & .459 & .849 \\
\hline Attitude 2 & $\mathrm{M}$ & 2.88 & 2.41 \\
& $\mathrm{SD}$ & .502 & .3. \\
\hline Attitude 3 & $\mathrm{M}$ & 3.89 & .734 \\
& $\mathrm{SD}$ & .899 & 3.83 \\
\hline
\end{tabular}

Nevertheless, the study concluded a significant difference in the mean total score of attitudes towards science sub-scales post-test scores between both groups. In addition, the mean total score in the dependent variables post-test for the experimental group was significantly higher than that of the control group for specific sub-scales. When considered separately, the results of the dependent variables ANOVA showed statistical significance for student attitude towards the nature of learning science (Mean Square $=8.203, \mathrm{~F}=17.593, p=0.001<0.05)$ and the interest in learning science (Mean Square $=$ $4.762, \mathrm{~F}=12.014, p=0.001<0.05$ ). However, the influence of the teacher and teaching strategy (Mean Square $=.074, \mathrm{~F}=.135, \mathrm{p}=.714>0.05)$ is not statistically significant, as presented in Table 11.

Table 11. Results of ANOVA for between-subjects effect of the research variables

\begin{tabular}{lcccccc}
\hline Source & $\begin{array}{c}\text { Dependent } \\
\text { variable post-test }\end{array}$ & $\begin{array}{c}\text { Type III sum of } \\
\text { squares }\end{array}$ & df & Mean square & F & p \\
\hline Group & Attitude 1 & 8.203 & 1 & 8.203 & 17.593 & .001 \\
& Attitude 2 & 4.762 & 1 & 4.762 & 12.014 & .001 \\
& Attitude 3 & .074 & 1 & .074 & .135 & .714 \\
\hline${ }^{*} p<.05$ & & & & &
\end{tabular}

The research findings revealed that middle school Saudi students have positive attitudes towards science. The results of the current research come in line with the findings of the studies conducted by Asiri (2018), and Saif and Aseri (2017), who concluded that Saudi students have positive attitudes towards science. Similarly, the research findings support the views of the research findings conducted by Sakariyau et al. (2016) in Nigeria, and Yunus and Ali (2013) in Malaysia. From another aspect, the research results are inconsistent with the research findings conducted by White and Harrison (2012) in the United Kingdom, revealing secondary students' negative attitudes towards science. Hence, we could conclude that Saudi students look at science as one of their favourite subjects so that they are almost interested in taking science classes and find easier challenges when doing assignments.

The determinations to stimulate the improvement of students' interests can be carried out in different ways. According to the findings of this research, scaffolding is an effective way to increase the students' interest in science owing to the diversities of strategies used by science teachers. Additionally, scaffolding is carried out to create authentic connections and expose the student to new experiences. Hence, scaffolding reinforces students' attitudes positively and thus encourages students to be committed and responsible. Annisa and Sutapa (2019) noted that scaffolding must be executed continuously to keep the children's interest in science until they gain the essential strategies to solve problems depending on their own experiences. 
As shown in this research, most of the participants have a positive attitude towards learning science because their teachers give them enough space for autonomy so that they are able to communicate their own experiences through the use of SS. The great majority of students who participated in this research do not reflect a positive attitude when they are taught using a conventional approach. Students have a minor role in being stable, just passively watching and listening to their teacher. The findings of the current research come in line with the viewpoint by Yunus and Ali (2013), who claim that students always prefer to deal with student-centred learning or hands-on activities rather than being bound to teacher-centred learning. Hence, we could argue that a teacher is a cornerstone in creating a suitable, interesting and motivating environment in the classroom, striking a balance between the students' needs and class requirements. In other words, teachers need to be motivated and enthusiastic to reinforce the students' attitudes by being more helpful and cooperating in science classes. In sum, the current research results show that science students have a positive attitude when they are given enough space to share their knowledge, which is more possible when scaffolding is applied. In doing so, students become highly motivated, and thus, they have the potential to overcome learning challenges because of the rapid increase in their interest in learning activities in general and science subject in particular.

However, owing to time constraints, the length of the study was limited to approximately 12 lessons. Arguably, a longer application period might be more advantageous to allow more time for evaluating the effects of the SS, which require richer materials and research. As a study that employs quasiexperimental data analysis, internal validity could be the main limitation because of the nature of this technique. That is, accuracy is more sensitive because the treatment and control groups may not be comparable at baseline. Considering such threats, the random assignment technique was applied where the classes were chosen randomly and had the same chance in terms of the intervention group and the comparison group of the study.

Based on the above issues, teachers seek the support of attitude and motivation theories that explain how to perform multiple tasks with high satisfaction in classrooms. Additionally, researchers can contribute by developing methods for enhancing students' attitudes in reliable ways throughout various learning activities so that they can explain their ideas in classrooms. Such methods can help teachers understand the significance of attitudes in playing a vital role in developing students' learning. From the study's findings, arguably, in many educational situations, such as those in Saudi Arabia, where the study was conducted, science teachers need to be trained on promoting students and developing their attitudes by applying SS in classrooms.

\section{CONCLUSION}

The research findings can conclude that SS are effective teaching-learning instruments compared with the conventional teaching-learning approaches. Hence, teachers of science should use SS to enhance students' learning on the one hand and to reinforce their attitudes towards the subject of science on the other hand. In addition to the teaching efforts, it could be recommended that more time be added the periods as SS require extra effort and time. Curriculum planners need to adopt SS as an appropriate teaching technique for teaching science, which can be textualised within the science syllabus and included in the teachers' guide. Moreover, training is the typical venue for developing science teachers' professionalism, particularly in using SS that can rapidly develop teaching-learning environments on local and global levels.

One important point that should be tackled here is that the educational system of Saudi Arabia is found to mainly stress the learning content and materials, which are related to high school curriculums, but this case needs to be the same with middle schools. Based on the current research results, scaffolding techniques should be developed in the educational environment because they are appropriate strategies in crafting a better science communication to build a better future. 


\title{
ABBREVIATIONS
}

MANCOVA: Multivariate analysis of covariance

\author{
M : Mean \\ SD $\quad$ : Standard Deviation \\ ZPD : : Zone of Proximal Development \\ SS : Scaffolding Strategies \\ 5Es : Engagement, Exploration, Explanation, Elaboration and Evaluation
}

Author contributions: All authors were involved in concept, design, collection of data, interpretation, writing, and critically revising the article. All authors approve final version of the article.

Funding: The authors would like to express special thanks and acknowledge the Ministry of Education and Universiti Kebangsaan Malaysia (UKM) (GG-2019-007).

Acknowledgements: The authors would like to express special thanks and acknowledge the Faculty of Education, Universiti Kebangsaan Malaysia (UKM), Malaysia, and the Ministry of Education Saudi Arabia for permitting to conduct the study, including the science teachers and students who participated in this study.

Declaration of interest: Authors declare no competing interest.

Data availability: The student survey and performance data analysed during the current study are not publicly available due to the Saudi Ministry of Education policies restrictions, but aggregated data are available from the authors on reasonable request.

\section{REFERENCES}

Adodo, S. O., \& Gbore, L. O. (2012). Prediction of attitude and interest of science students of different ability on their academic performance in basic science. International Journal of Psychology and Counselling, 4(6), 68-72. https://doi.org/10.5897/IJPC10.049

Agu, P. A., \& Iyamu, C. O. (2020). Effect of metacognitive scaffolding teaching strategy on secondary school physics students' achievement and attitude to thermal energy. International Journal of Scientific Advances, 1(2), 100-104. https://doi.org/10.51542/ijscia.v1i2.5

Ahmad, N., Shaheen, N., \& Gohar, S. (2018). 5E instructional model: Enhancing students academic achievement in the subject of general science at primary level. Sir Syed Journal of Education \& Social Research, 1(1), 90-100.

Alharbi, H. H. (2015). Internal and external efficiency of the Saudi education system. International Journal of Humanities and Social Science, 8(1), 91-98.

Almazroa, H., \& Al-Shamrani, S. (2015). Saudi science teacher professional development: Trends, practices and future directions. In Science education in the arab gulf states (pp. 1-21). Brill Sense. https://doi.org/10.1007/978-94-6300-049-9_1

Almuntasheri, S., Gillies, R. M., \& Wright, T. (2016). The effectiveness of a guided inquiry-based, teachers' professional development programme on Saudi students' understanding of density. Science Education International, 27(1), 16-39.

Alrwathi, E., Almazroa, H., Alahmed, N., Scantbly, C., \& Alshaye, F. (2014). Exploring curriculum implementation: Focus on science teaching [Paper presentation]. 2nd IHPST Asian Regional Conference. Taipei, Taiwan, 4-7.

Al-Shargi, M. R. (1987). Saudi and non-Saudi Arab male students' attitudes toward science and science achievement in secondary schools [Doctoral dissertation, Oregon State University]. Corvallis.

Altiparmak, T., \& Eryilmaz-Muştu, O. (2021). The effects of SCAMPER technique activities in the 8th grade simple machines unit on students' academic achievement, motivation and attitude towards science lessons. International Journal of Educational Methodology, 7(1), 155-170. https://doi.org/10.12973/ijem.7.1.155

Annisa, A., \& Sutapa, P. (2019). Scaffolding strategies to increase children science interest. International Conference on Special and Inclusive Education (ICSIE 2018), 296, 279-284. https://doi.org/10.2991/icsie-18.2019.50

Artino, A. R. (2012). Academic self-efficacy: From educational theory to instructional practice. Perspectives on Medical Education, 1 , 76-85. https://doi.org/10.1007/s40037-012-0012-5

Asiri, A. A. M. (2018). Attitudes of secondary school students in Saudi Arabia towards science. International Journal of Education, Learning and Development, 6(3), 30-36.

Azevedo, F. S. (2018). An inquiry into the structure of situational interests. Science Education, 102(1), 108-127. https://doi.org/10.1002/sce.21319

Azevedo, R., \& Hadwin, A. F. (2005). Scaffolding self-regulated learning and metacognition - Implications for the design of computer-based scaffolds. Instructional Science, 33(5-6), 367-379. https://doi.org/10.1007/s11251-005-1272-9 
Barak, M., \& Dori, Y. J. (2009). Enhancing higher order thinking skills among inservice science teachers via embedded assessment. Journal of Science Teacher Education, 20(5), 459-474. https://doi.org/10.1007/s10972-009-9141-z

Bybee, R. (1997). Achieving scientific literacy: From purposes to practices. Heinemann Publications.

Bybee, R. W., \& Landes, N. M. (1990). Science for life \& living: An elementary school science program from biological sciences curriculum study. The American Biology Teacher, 52(2), 92-98. https://doi.org/10.2307/4449042

Carin, A. A., Bass, J. E., \& Contant, T. L. (2005). Teaching science as inquiry. Prentice Hall.

Casem, R. Q., \& Alicia, F. O. (2013). Scaffolding strategy in teaching mathematics: Its effects on students' performance and attitudes. Comprehensive Journal of Educational Research, 1(1), 9-19.

Cermik, H., \& Fenli-Aktan, A. (2020). Primary school students' attitudes towards science. International Journal of Educational Methodology, 6(2), 355-365. https://doi.org/10.12973/ijem.6.2.355

Chang, J. Y. T., Wang, E. T. G., \& Chao, R.-M. (2009). Using constructivism and scaffolding theories to explore learning style and effect in blog system environment. MIS REVIEW: An International Journal, 15(1), 29-61.

Cheng, K., \& Tsai, C. (2020). Students' motivational beliefs and strategies, perceived immersion and attitudes towards science learning with immersive virtual reality: A partial least squares analysis. British Journal of Educational Technology, 0(0), 120. https://doi.org/10.1111/bjet.12956

Chitman-Booker, L., \& Kopp, K. (2013). The 5Es of inquiry-based science. Teacher Created Materials.

Darling-Hammond, L., Flook, L., Cook-Harvey, C., Barron, B., \& Osher, D. (2020). Implications for educational practice of the science of learning and development. Applied Developmental Science, 24(2), 97-140. https://doi.org/10.1080/10888691.2018.1537791

DeCoster, J. (2006). Testing group differences using t-tests, ANOVA, and nonparametric measures. http://www.stat-help.com/ANOVA 2006-01-11.pdf

Derez, R. L. (2021). Building the interest of grade three pupils in science subject through HOOD collaborative approach (Helping others observe and discover). International Journal of Research in Engineering, Science and Management, 4(6), 284-286.

Dorn, L. J., \& Soffos, C. (2001). Scaffolding young writers: A writer's workshop approach. Stenhouse Publishers.

Fraenkel, J. R., \& Wallen, N. E. (1996). How to design and evaluate research (3rd ed). McGraw-Hill.

Fraser, B. J. (1981). Test of science-related attitudes (TOSRA). Australian Council for Educational Research. http://www.pearweb.org/atis/data/documents/000/000/004/TOSRA_BJF_.pdf

George, R. (2006). A cross-domain analysis of change in students' attitudes toward science and attitudes about the utility of science. International Journal of Science Education, 28(6), 571-589. https://doi.org/10.1080/09500690500338755

Grewal, A. (1990). Scientific Attitude Scale (SAS). National Psychological Corporation Agra.

Hausfather, S. (2001). Where's the content? The role of content in constructivist teacher education. Horizons, 80(1), 15-19.

Ibritam, K. S., Udofia, N.-A., \& Onweh, V. E. (2015). Assessing the potency of scaffolding and demonstration instruction methods on student's achievement in technical colleges in Akwa Ibom State. Advances in Research, 3(1), 92-101. https://doi.org/10.9734/AIR/2015/12182

Jorde, D., \& Dillon, J. (2012). Science education research and practice in Europe: retrospective and prospective. In Science education research and practice in Europe (pp. 1-11). Brill Sense. https://doi.org/10.1007/978-94-6091-900-8_1

Kim, P., Suh, E., \& Song, D. (2015). Development of a design-based learning curriculum through design-based research for a technology-enabled science classroom. Educational Technology Research and Development, 63(4), 575-602. https://doi.org/10.1007/s11423-015-9376-7

King, F. J., Goodson, L., \& Rohani, F. (2013). Higher order thinking skills: Definition, teaching strategies, assessment. Center for Advancement of Learning and Assessment. https://informationtips.files.wordpress.com/2016/02/higher-order-thinkingskills_.pdf

Kiong, P. L. N., \& Yong, H. T. (2001). Scaffolding as a teaching strategy to enhance mathematics learning in the classroom. In Proceeding of the 2001 Research Seminar in Science and Mathematics Education.

Lajoie, S. P. (2014). Multimedia learning of cognitive processes. In R. E. Mayer (Ed.), The Cambridge Handbook of Multimedia Learning (pp. 623-646). Cambridge University Press. https://doi.org/10.1017/CBO9781139547369.031

Lajoie, Susanne P. (2005). Extending the scaffolding metaphor. Instructional Science, 33(5-6), 541-557. https://doi.org/10.1007/s11251-005-1279-2

Liou, P. Y. (2021). Students' attitudes toward science and science achievement: An analysis of the differential effects of science instructional practices. Journal of Research in Science Teaching, 58(3), 310-334. https://doi.org/10.1002/tea.21643

Liou, P.-Y. (2014). Examining the big-fish-little-pond effect on students' self-concept of learning science in Taiwan based on the TIMSS databases. International Journal of Science Education, 36(12), 2009-2028. https://doi.org/10.1080/09500693.2014.889331

Liou, P.-Y., Wang, C.-L., Lin, J. J. H., \& Areepattamannil, S. (2020). Assessing students' motivational beliefs about learning science across grade level and gender. Journal of Experimental Education, 89(4), 605-624. https://doi.org/10.1080/00220973.2020.1721413

Lorsbach, A. (2006). The learning cycle as a tool for planning science instruction. IIIinois State University. 
Mansour, N., \& Al-Shamrani, S. (2015). Science education in the Arab Gulf states: Visions, sociocultural contexts and challenges. Springer. https://doi.org/10.1007/978-94-6300-049-9

National Research Council (NRC). (2012). A framework for K-12 science education: Practices, crosscutting concepts, and core ideas. The National Academies Press.

Nonye, A., \& Nwosu, B. O. (2011). Effects of instructional scaffolding on the achievement of male and female students in financial accounting in secondary schools in abakaliki urban of Ebonyi state, Nigeria. Current Research Journal of Social Sciences, 3(2), 66-70.

Obeikan for Research and Development. (2010). Project of mathematics and natural sciences.

Olatoye, R. A., Aderogba, A. A., \& Aanu, E. M. (2011). Effect of co-operative and individualized teaching methods on senior secondary school students' achievement in organic chemistry. The Pacific Journal of Science and Technology, 12(2), 310-319.

Osborne, J., Simon, S., \& Collins, S. (2003). Attitudes towards science: A review of the literature and its implications. International Journal of Science Education, 25, 1049-1079. https://doi.org/10.1080/0950069032000032199

Pallant, J. F. (2000). Development and validation of a scale to measure perceived control of internal states. Journal of Personality Assessment, 75(2), 308-337. https://doi.org/10.1207/S15327752JPA7502_10

Papanastasiou, C., \& Papanastasiou, E. C. (2004). Major influences on attitudes toward science. Educational Research and Evaluation, 10(3), 239-257. https://doi.org/10.1076/edre.10.3.239.30267

Pea, R. D. (2004). The Social and Technological Dimensions of Scaffolding and Related Theoretical Concepts for Learning, Education, and Human Activity. Journal of the Learning Sciences, 13(3), 423-451. https://doi.org/10.1207/s15327809jls1303_6

Pekrun, R., \& Marsh, H. W. (2018). Weiner's attribution theory: Indispensable - But is it immune to crisis?. Motivation Science, 4(1), 19-20. https://doi.org/10.1037/mot0000096

Pickering, D. J., \& Marzano, R. J. (2011). The highly engaged classroom. Marzano Research Laboratory.

Renken, M., Otrel-Cass, K., Chiocarriello, A., Girault, I., \& Peffer, M. (2016). Scaffolding science learning: Promoting disciplinary knowledge, science process skills, and epistemic processes. In Simulations as scaffolds in science education (pp. 23-28). Springer. https://doi.org/10.1007/978-3-319-24615-4_5

Rosemond, D. G. (2006). Acquisition of scientific attitudes and its relevance to science educators [Paper presentation]. Median Seminar of Faculty of Sciences.

Saif, A., \& Asiri, A. (2017). Attitudes of elementary schools students in Najran District towards science. Journal of Education and Practice, 8(27), 231-238.

Sakariyau, A. O., Taiwo, M. O., \& Ajagbe, O. W. (2016). An investigation on secondary school students' attitude towards science in Ogun State, Nigeria. Journal of Education and Practice, 7(28), 125-128.

Samuels, P., \& Gilchrist, M. (2014). Paired samples t-test. www.statstutor.ac.uk

Sekaran, U. (2003). Research methods for business: A skill-building approach (4th ed.). John Wiley \& Sons.

Senemoglu, N. (2018). Development, learning and teaching: From theory to practice (25th ed.). Memoir Publishing.

Shadish, W. R., Cook, T. D., \& Campbell, D. T. (2002). Experimental and quasi-experimental designs for generalized causal inference. Wadsworth Cengage Learning.

Tabachnick, B., \& Fidell, L. (2019). Using multivariate statistics (7th ed.). Pearson Education.

Tayeb, Y. A., Abd Aziz, M. S., Ismail, K., \& Khan, A. B. M. A. (2014). The washback effect of the general secondary English examination (GSEE) on teaching and learning. GEMA Online ${ }^{\circledR}$ Journal of Language Studies, 14(3), 83. https://doi.org/10.17576/GEMA-2014-1403-06

Thomas, R., Koballa, J., \& Crawley, F. (1985). The influence of attitude on science teaching and learning. School Science and Mathematics, 85(3), 222-232. https://doi.org/10.1111/j.1949-8594.1985.tb09615.x

Ugulu, I. (2015). Development and validation of an instrument for assessing attitudes of high school students about recycling. Environmental Education Research, 21(6), 916- 942. http://doi.org/10.1080/13504622.2014.923381

Ugulu, I. (2020). Gifted students' attitudes towards science. International Journal of Educational Science, 28(1-3), 7-14. https://doi.org/10.31901/24566322.2020/28.1-3.1088

Ural, E., \& Gençoğlan, D. M. (2020). The effect of argumentation-based science teaching approach on 8th graders' learning in the subject of acids-bases, their attitudes towards science class and scientific process skills. Interdisciplinary Journal of Environmental and Science Education, 16(1), e02207. https://doi.org/10.29333/ijese/6369

Van de Pol, J., Mercer, N., \& Volman, M. (2019). Scaffolding student understanding in small-group work: Students' uptake of teacher support in subsequent small-group interaction. Journal of the Learning Sciences, 28(2), 206-239. https://doi.org/10.1080/10508406.2018.1522258

Van de Pol, J., Volman, M., \& Beishuizen, J. (2010). Scaffolding in teacher-student interaction: A decade of research. Educational Psychology Review, 22(3), 271-296. https://doi.org/10.1007/s10648-010-9127-6

White, E. L., \& Harrison, T. G. (2012). UK School Students' Attitudes towards Science and Potential Science-Based Careers. Acta Didactica Napocensia, 5(4), 1-10. 
Yee, M. H., Yunos, J., Othman, W., Hassan, R., Tee, T. K., \& Mohaffyza, M. (2015). Disparity of Learning Styles and Higher Order Thinking Skills among Technical Students. Procedia - Social and Behavioral Sciences, 204, 143-152. https://doi.org/10.1016/j.sbspro.2015.08.127

Yunus, F. W., \& Ali, Z. M. (2013). Attitude towards learning chemistry among secondary school students in Malaysia. Journal of Asian Behavioural Attitude, 3(11), 1-12. 